Outros Tempos, vol. 17, n. 29, 2020, p. 260 - 281. ISSN: 1808-8031

\title{
DOI: http://dx.doi.org/10.18817/ot.v17i29.776
}

(MAIS)CULINOS: outras possibilidades de corpos e gêneros para as carnes sexuadas pela presença de um pênis ${ }^{1}$

(MORE)CULINES: other possibilities of bodies and genders for flesh sexed by the presence of a penis

(MAIS)CULINOS: otras posibilidades de cuerpos y de géneros para las carnes sexuadas por la presencia de un pene

\section{DURVAL MUNIZ DE ALBUQUERQUE JÚNIOR Doutor em História Social Universidade Estadual da Paraíba João Pessoa/Paraíba/Brasil durvalaljr@gmail.com}

Resumo: Partindo de uma diferenciação conceitual entre carne e corpo, esse texto discute como as atribuições sociais e culturais de identidades de sexo e gênero, para dadas carnes, são fundamentais na construção de corpos vistos e ditos como de machos e como masculinos. Tomando como objeto de análise um conto do escritor pernambucano Marcelino Freire, o conto Júnior, presente no seu livro Rasif: mar que arrebenta, o texto procura exemplificar como as carnes que nascem sexuadas com um pênis não estão condenadas pela natureza, ou pela divindade, a vir a configurarem corpos de machos ou corpos masculinos. $\mathrm{O}$ texto busca deixar claro que há mais masculinos do que as visões naturalistas e deterministas procuram afirmar.

Palavras-chave: Carne. Corpo. Masculinidades.

Abstract: Starting from a conceptual differentiation between flesh and body, this text examines how the social and cultural attributions of sex and gender identities, for the given fleshes, are fundamental in the construction of bodies viewed and called male and masculine. Taking as object of analysis a short story by Pernambuco writer Marcelino Freire, O Conto Junior, present in his book Rasif: sea that breaks, our text seeks to exemplify how the flesh born with a penis is not condemned by nature, or by a deity, to eventually become male or masculine bodies. The text seeks to clear that there are more masculine forms than naturalist and deterministic views state.

\section{Keywords: Flesh. Body. Masculinities.}

Resumen: Partiendo de una diferenciación conceptual entre carne y cuerpo, ese texto analiza como las atribuciones sociales y culturales de identidades de sexo y género, para dadas carnes, son fundamentales en la construcción de cuerpos vistos y dichos como de machos y como masculinos. Tomando como objeto de análisis un cuento del escritor de Pernambuco, Marcelino Freire, el cuento Júnior, presente en su libro Rasif: mar que arrebenta, el texto busca ejemplificar como las carnes nascidas con un pene no están condenadas por la naturaleza, o por la divinidad, a venir a configuraren cuerpos de machos o cuerpos masculinos. El texto busca dejar en claro que hay más masculinos del que las visiones naturalistas y deterministas afirman.

Palabras clave: Carne. Cuerpo. Masculinidades.

\footnotetext{
${ }^{1}$ Artigo submetido à avaliação em junho de 2019 e aprovado para publicação em dezembro de 2019.
} 
Outros Tempos, vol. 17, n. 29, 2020, p. 260 - 281. ISSN: 1808-8031

\section{Entre carnes e corpos}

Ninguém nasce com um corpo. Nascemos com carnes, matéria indispensável para construirmos corpos. Por sermos seres culturais, não nos bastam as carnes, que a natureza nos deu, para que tenhamos corpo. Como seres que nascemos imersos na linguagem, no conceito, precisamos mais do que matérias, como as carnes, para elaborarmos um corpo, pois ele é, antes de tudo, um conceito, que precisamos aprender com a nossa cultura, que precisamos encarnar. Nós humanos usamos as carnes, que nos foram dadas, para encarnar, para materializar conceitos, concepções, modelos socialmente definidos e elaborados de corpo. Não nascemos com corpos, mas aprendemos a ser corpo, aprendemos a transformar carnes em corpos. Quando a criança nasce ela é apenas um animalzinho, nem humana é ainda. Ela não possui a menor consciência corporal, ou seja, ela ainda não possui um corpo, pois tê-lo depende dessa consciência, desse aprendizado, de uma percepção das carnes como corpo, que só vai adquirindo à medida que se socializa, que vai incorporando a sua cultura, as categorias e conceitos que sua ordem social e cultural tem a oferecer a respeito da corporeidade. Cada ser humano possui o corpo que sua cultura permite, que sua ordem social prescreve e possibilita. Possuir um corpo depende de um aprendizado, de processos educativos, de pedagogias que atuam no cotidiano e nos vários âmbitos da vida social. Portanto, uma visão meramente biológica, meramente naturalista do corpo humano não se sustenta. A biologia, a genética, a neurociência dão conta das carnes, mas nunca dos corpos, nunca dão conta daquilo que fazemos, que fabricamos com as carnes, que nos foram dadas no nascimento ${ }^{2}$.

O corpo é, portanto, um artefato, uma construção humana. Para fabricarmos um corpo humano é preciso bem mais do que carnes. Como já vimos, precisamos de um conceito, de um modelo, de um projeto de corpo. Fabricamos corpos com carnes e conceitos. Mas também utilizamos, nessa fabricação, outras matérias, outros materiais, para além das carnes que nos são dadas ao nascer. Desde as mais simples das culturas humanas, quando uma criança nasce trata-se de, imediatamente, acrescentar às suas carnes outros artefatos materiais, de preferência artefatos construídos pela mão humana, para fazer com que aquelas carnes entrem na ordem social, façam parte do mundo humano. Quando em meio às carnes que nascem enxerga-se um pênis, trata-se de colocar um arco nas mãos ou ao lado da criança, dando início à implantação naquele corpo do ser macho e do ser masculino, da mesma forma que, se ao visualizar as carnes que acabam de nascer identifica-se uma vagina, trata-se de

\footnotetext{
${ }^{2}$ DEJOURS, Christophe; DRESCH, Vanise. Primeiro, o corpo: corpo biológico, corpo erótico e senso moral. Porto Alegre: Dublinense, 2019.
} 
Outros Tempos, vol. 17, n. 29, 2020, p. 260 - 281. ISSN: 1808-8031

colocar um cesto ao lado da criança para marcá-la, de saída, como carnes fêmeas e que deve vir a se transformar em carnes femininas ${ }^{3}$. A incorporação dessas carnes à ordem social começa a se fazer à medida que elas são imediatamente classificadas, usando-se as categorias disponíveis naquela cultura para separar carnes que trazem pênis e carnes que trazem vagina, realizando o que Judith Butler nomeou de implantação do sexo nos corpos ${ }^{4}$. As carnes em si mesmas não sabem que são carnes de macho e carnes de fêmea, pois as categorias sexuais, as categorias que sexualizam, que dotam os corpos de um sexo, são categorias da cultura. Macho e fêmea são categorias culturais, são conceitos, que não estão tatuados nas carnes. Seria perfeitamente possível que uma cultura classificasse como macho carnes dotadas de vagina e como fêmea carnes dotadas de pênis. As categorias culturais são convenções, são acordos, são consensos que, no entanto, são, muitas vezes, naturalizados, dado o grau de ancestralidade, de antiguidade, de tradicionalidade que possuem. Elas operam como parte de estruturas sociais inconscientes e, por isso mesmo, tidas como naturais, como eternas e, até mesmo, como vinda dos deuses, das divindades. Não é nenhuma heresia afirmarmos que nascemos sem sexo, apesar de nascermos com órgãos que servirão para nos sexualizar, órgãos que servirão de referência para que nossos corpos sejam distribuídos dentro das categorias binárias de classificação que caracterizam a maioria das culturas humanas ${ }^{5}$. No entanto, essas categorias entram em crise, entram em pane, diante de carnes que nascem com pênis e vagina, que nascem com traços anatômicos que não permitem atirar essas carnes, facilmente, para a gaveta dos machos ou para a gaveta das fêmeas. A natureza tida como binária, como sendo a garantia de que nascemos macho ou fêmea, que serve de fundamento e justificativa, que legitima a forma binária das culturas sexualizarem as carnes e construírem corpos, que serve de argumento para os discursos naturalizadores do sexo, mostra-se muito mais criativa e surpreendente, muito distinta da forma como a concebemos e pensamos. Vemos nisso anomalia e monstruosidade e, de forma arrogante, tratamos de corrigir a natureza, para que as carnes se conformem às nossas categorias binárias de classificação sexual. Atribuímos aos médicos e às famílias o poder de fazer intervenções cirúrgicas nessas carnes para que elas se encaixem em nossas categorias binárias de definição do sexo. Nesses casos, literalmente, inicia-se a fabricação de um corpo, binariamente sexuado, a golpes de bisturi. O sexo é literalmente implantado nas carnes, só que por ações de supressão e de mutilação. Mas a natureza, tida por muitos como uma garantia de suas visões binárias, é mais surpreendente,

\footnotetext{
${ }^{3}$ LEVI-STRAUSS, Claude. As estruturas elementares do parentesco. 7. ed. Petrópolis: Vozes, 2012.

${ }^{4}$ BUTLER, Judith. Problemas de gênero. Rio de Janeiro: Civilização Brasileira, 2017.

${ }^{5}$ PRECIADO, Beatriz. Manifesto contrassexual: práticas subversivas de identidade sexual. São Paulo: N-1, 2011.
} 
Outros Tempos, vol. 17, n. 29, 2020, p. 260 - 281. ISSN: 1808-8031

mais poética do que as concepções modernas, mecânica e/ou orgânica dessa natureza, podem aceitar $^{6}$. Ela dribla esses procedimentos autoritários de produção de carnes sexuadas, fazendo que carnes nasçam fora dos padrões binários da sociedade e sem que possam sofrer as mutilações visando à "correção" do pretenso desvio da norma: carnes ditas intersexuadas geneticamente, que possuem cromossomos ditos masculinos e femininos, carnes ditas intersexuadas hormonalmente, carnes que surgem rebeladas em relação ao binarismo que absolutizamos em nossas culturas ao constatarmos a sua prevalência na natureza ${ }^{7}$.

Durante muito tempo, o corpo dos humanos era um corpo coletivo, era o próprio corpo da comunidade, da aldeia, do clã, não se pensava e não existia um corpo individualizado $^{8}$. Em muitas culturas humanas, antes de tudo, as carnes humanas faziam corpo com a terra, era na conexão com a terra, e com tudo que a compunha, desde as matas, os animais, as espécies vegetais e minerais, até os espíritos benfazejos ou malfazejos, os espíritos dos antepassados e dos mortos, que um corpo coletivo e humano se organizava 9 . Todo corpo é uma forma de organização de órgãos, que não se restringem necessariamente aos órgãos feitos de carne humana. Quando Antonin Artaud criou a imagem de um corpo sem órgãos, de um corpo que ameaçava se despedaçar, em que dados órgãos esquizofrenizavam, pareciam ganhar vida própria, terem vontades próprias, agirem sozinhos, funcionarem sem a necessidade do engajamento de todo corpo na ação que realizavam, ele chamava atenção para o fato de que nossa maneira de enxergar o corpo como um organismo, como uma articulação de órgãos que trabalham todos articulados e em um mesmo sentido, é apenas uma dada forma de pensar e de conceber o corpo, a forma como a cultura ocidental moderna pensa e vê o corpo, é um conceito de corpo, distinto daquelas visões em que para se fazer um corpo é ou era preciso articular nossas carnes, nossos órgãos a outros materiais e a outros organismos mais amplos do que o nosso, como seria o caso da terra, daquilo que se vai chamar, a partir do século XVII, de natureza ${ }^{10}$.

Mas continuamos necessitando de outros materiais, para além das carnes, para elaborarmos nossos corpos. As carnes para se tornarem corpos sempre precisaram de

\footnotetext{
${ }^{6}$ WULF, Andrea. A invenção da natureza: a vida e as descobertas de Alexander von Humboldt. São Paulo: Crítica, 2019.

${ }^{7}$ PRETES, Érika. Intersexualidade e direito ao corpo. São Paulo: Initia Via Editora, 2019.

${ }^{8}$ CASTRO, Eduardo Viveiros de. Metafísicas canibais: elementos para uma antropologia pós-estrutural. São Paulo: N-1, 2018.

${ }^{9}$ DELEUZE, Gilles; GUATTARI, Félix. $O$ anti-Édipo: capitalismo e esquizofrenia. São Paulo: Editora 34, 2010.

${ }^{10}$ DELEUZE, Gilles; GUATTARI, Félix. 28 de novembro de 1947: como criar para si um corpo sem órgãos. In: DELEUZE, Gilles; GUATTARI, Félix. Mil platôs: capitalismo e esquizofrenia. São Paulo: Editora 34, 1996. v. 3, p. 9-30.
} 
Outros Tempos, vol. 17, n. 29, 2020, p. 260 - 281. ISSN: 1808-8031

complementos, de adornos, de vestimentas, de marcas, de assinalações. As carnes sempre precisaram entrar no mundo do símbolo, no mundo da cultura para passarem a ser parte dos corpos humanos. Um corpo humano é feito de carnes, mas é também feito de ornamentos, de vestimentas, de calçados, de adereços, de pinturas, de maquiagens, de tatuagens, de escarificações, da encarnação, enfim, de um conceito de corpo, social e culturalmente elaborado. O corpo humano é feito de carnes e imagens, ele é produto da encarnação de um imaginário. Ele é feito de carnes e fantasias, de carnes e sonhos, de carnes e utopias, de carnes e ilusões, de carnes e alusões. O corpo humano é muito mais do que aquele corpo pretensamente natural da biologia, das ciências da saúde que, na verdade, participam com seus conceitos e práticas da transformação de carnes em corpos, por elas fabricados, mas o corpo humano é a encarnação de projetos e modelos de corpos, cultural e socialmente produzidos. Quantas tecnologias não estão hoje investidas nas fabricações de corpos, inclusive tecnologias médicas: as intervenções das cirurgias plásticas, dos procedimentos estéticos e dermatológicos, dos chamados procedimentos corretivos, das tecnologias farmacológicas. Do odontólogo ao fisioterapeuta, do dermatologista ao esteticista, do nutricionista ao cirurgião, todos participam das transformações das carnes em corpos sonhados e desejados por seus clientes. Vivemos no interior de uma maquinaria social de produção de corpos, como nenhuma sociedade anterior dispôs, embora todas elas se caracterizaram por serem dotadas de dispositivos voltados para a produção dos corpos que aquela ordem social, cultural, econômica e política necessitava ${ }^{11}$.

As sociedades em que vivemos, as sociedades contemporâneas, notabilizam-se pela produção de corpos maquínicos, pela fabricação de corpos através do acoplamento de carnes e máquinas ${ }^{12}$. Todas as sociedades humanas construíram corpos acoplando, relacionando carnes e artefatos. Como já teorizava o marxismo, a humanidade foi fruto do acoplamento da mão humana com as ferramentas, que se tornaram um prolongamento de dados membros, de dados órgãos humanos. O trabalho, pensado como a atividade ontológica do humano, como a atividade que transformou o macaco em homem, exigia, de saída, que o corpo humano fosse constituído de algo mais do que suas carnes ${ }^{13}$. Carnes frágeis, pouco dotadas de atributos naturais, encontraram no acoplamento, na articulação com órgãos não humanos, com complementos técnicos feitos pelo próprio homem, a forma privilegiada de se

\footnotetext{
${ }^{11}$ CORBIN, Alain; VIGARELlO, Georges; COURTINE, Jean-Jacques. História do corpo 3: as mutações do olhar. O século XX. 4. ed. Petrópolis: Vozes, 2011.

${ }^{12}$ LAZZARATO, Maurizio. Signos, máquinas, subjetividades. São Paulo: N-1, 2013.

${ }^{13}$ ENGELS, Friedrich. Sobre o papel do trabalho na transformação do macaco em homem. São Paulo: Amazon E-Books, s/d.
} 
Outros Tempos, vol. 17, n. 29, 2020, p. 260 - 281. ISSN: 1808-8031

fazer corpos. O corpo do caçador necessitou, desde cedo, de mais do que as carnes humanas para ser fabricado: ele é inseparável da conexão carnes humanas, mão e olhos, cérebro, nervos, ossos, pele com a arma, por mais primitiva que tenha sido: o corpo do caçador é feito de carnes e pedras, de carnes e fundas, de carnes e arcos, e flechas, e massas, e armas de fogo. A linha de montagem da indústria moderna monta mais do que mercadorias e produtos, faz a montagem de outros corpos para os trabalhadores. Um corpo feito de carnes, mas também feito de adestramentos, de disciplinas, da encarnação de gestos rotineiros, da encarnação de reações e ações, da encarnação de ritmos, de velocidades, de deslocamentos, de habilidades. As carnes, muitas vezes, sofrem, são torturadas, são tensionadas, são exigidas em suas máximas disposições para que se tornem esses corpos que a grande máquina técnica da fábrica necessita. $\mathrm{O}$ corpo coletivo exigido pela indústria moderna faz-se através da conexão das carnes dos trabalhadores às máquinas e dispositivos técnicos e tecnológicos, que os levam a fabricarem corpos para o trabalho, distinto dos corpos que são fabricados nas atividades de lazer, nas atividades religiosas, nas atividades políticas ${ }^{14}$.

Sim, fabricamos corpos que são convocados e requeridos pelas instituições sociais e seus rituais. O corpo é uma fabricação ritual, utilizando máscaras ou ornamentos, produzindo dados rostos e dados gestos, tornamos nossas carnes adequadas a ocuparem os lugares de sujeito, os personagens, que os rituais sociais exigem. Como nos falava o antropólogo Erving Goffman, a vida social é dramatúrgica, nela aprendemos a realizar performances, cenas, encenações e a encarnar personagens ${ }^{15}$. Os corpos são inseparáveis dos personagens que precisamos encarnar em dadas situações e em dadas instituições. Usamos nossas carnes e uma série de outros materiais e tecnologias para produzirmos o corpo que uma dada encenação social, que uma dada performance e uma dada personagem nos exige. Há um corpo para o ritual da conquista amorosa e sexual, há um corpo para o trabalho, há um corpo para a festa, há um corpo para o culto e a oração, há um corpo para a viagem e para a diversão, há um corpo para a escola e para a educação física. Os corpos são de passagem porque são fabricações circunstanciais, são produções voltadas para atender um dado contexto de ação e de enunciação ${ }^{16}$. Fabricamos corpos adequados às mensagens que queremos transmitir, os corpos são linguagem, são símbolo, são signos, por isso significam e comunicam. Usamos nossas carnes para organizar um corpo que, numa dada situação, comunique alguma coisa, passe uma mensagem, faça visível uma dada enunciação. Corpos

\footnotetext{
${ }^{14}$ FEDERICI, Silvia. Calibã e a bruxa: mulheres, corpos e acumulação primitiva. São Paulo: Elefante, 2019.

${ }^{15}$ GOFFMAN, Erving. Representação do eu na vida cotidiana. 20. ed. Petrópolis: Vozes, 2014.

${ }^{16}$ SANT'ANNA, Denise Bernuzzi de. Corpos de passagem. São Paulo: Estação Liberdade, 2001.
} 
Outros Tempos, vol. 17, n. 29, 2020, p. 260 - 281. ISSN: 1808-8031

podem ser fabricados para serem bandeiras, para se fazerem mensagem e enunciação política, como a fabricação de corpos pelas manifestações políticas de feministas e homossexuais, de negros e indígenas têm explicitado ${ }^{17}$.

Como têm deixado claro as chamadas histórias do corpo que, muitas vezes, podem passar a mensagem equivocada de que algo como o corpo sempre teria existido, há formas distintas de pensar e de fabricar corpos, ao longo da história ocidental ${ }^{18}$. Elas deveriam se chamar de história das carnes, tal como foi esboçada no último volume da História da Sexualidade, infelizmente deixado inacabado por Michel Foucault ${ }^{19}$. Se a Igreja Católica utilizava a noção de carne, para falar da condição material da existência humana, é porque ela manejava um outro conceito de corpo. O corpo para o cristianismo tinha uma dimensão espiritual, uma dimensão sobrenatural, que extrapolava as carnes. Como mostram essas ditas histórias do corpo, para a pastoral cristã, o corpo era inseparável da alma. Após a morte, teríamos a corrupção, a putrefação das carnes, mas não o apodrecimento do corpo, que readquiriria sua dimensão espiritual e faria sua ascensão aos céus ou a descida aos infernos. Como nos mostra Georges Vigarelo, durante muito tempo sequer tivemos uma percepção apurada de nossas carnes. As teorias médicas prevalecentes desde a Antiguidade faziam do corpo um invólucro, uma espécie de armadura que cercava e limitava a alma. As carnes eram vistas como configurando um corpo que só possuía sensibilidade exterior, dada pelos órgãos do sentido. Foi apenas na passagem do século XVIII para o século XIX, que se desenvolveu uma visão interiorizada do corpo, uma consciência de si, que foi se transformando numa visão psicológica do corpo, uma visão que pensava as carnes produzindo o corpo com uma sensibilidade interna própria, um sentimento de um si mesmo, individualizado ${ }^{20}$. Somente com a emergência da anatomoclínica, na segunda metade do século XVIII, é que passa a se considerar a existência de um corpo que adoece na realidade mesma de suas carnes. Durante séculos a medicina hipocrática fez pensar que as doenças era entidades, realidades extracorporais, que invadiam as carnes em suas porosidades, que delas se apossavam. Um corpo concebido como atravessado por fluxos de humores, que podiam ser bloqueados, interrompidos, causando dadas enfermidades. A partir do século XVII, pensa-se um corpo

\footnotetext{
${ }^{17}$ FONTANILLE, Jacques. Corpo e sentido. Londrina: EDUEL, 2011.

${ }^{18}$ CORBIN; VIGARELLO; COURTINE, op. cit., 2011.

${ }^{19}$ FOUCAULT, Michel. História da sexualidade IV: as confissões da carne. Lisboa: Relógio D’Água, 2019.

${ }^{20}$ VIGARELLO, Georges. Sentimento si: história da percepção do corpo (séculos XVI-XX). Petrópolis: Vozes, 2016.
} 
Outros Tempos, vol. 17, n. 29, 2020, p. 260 - 281. ISSN: 1808-8031

atravessado de energias, de reações nervosas, de disparos elétricos, de correntes que desviadas ou em mal funcionamento causavam as moléstias ${ }^{21}$.

Hoje, nossas teorias médicas julgam-se conhecedoras do verdadeiro corpo, como as anteriores também se arrogaram, mas, na verdade, participam da construção de um dado conceito de corpo, manejando, nomeando, conceituando, intervindo com as manifestações, muitas vezes misteriosas, das carnes ${ }^{22}$. Ao mesmo tempo, os discursos religiosos continuam competindo, assim como fazem os discursos jurídico, pedagógico, ético, moral, na conceituação e definição do que seja, inclusive, o princípio mesmo que define e particulariza as carnes dos chamados seres vivos, entre os quais os humanos se encontram: a vida ${ }^{23}$. As religiões continuam fabricando corpos a partir de suas concepções e conceitos do que deve ser um corpo adequado às suas crenças e de qual o corpo requerido pela própria divindade ${ }^{24}$. Se no candomblé se faz a cabeça, vemos desfilar, ao lado, corpos terrivelmente evangélicos, corpos iogues, corpos budistas, corpos muçulmanos, corpos judaicos, etc. ${ }^{25}$ Os códigos e regras que regem as práticas e crenças religiosas levam até a mutilação das carnes para que essas se adequem ao protótipo de corpo que eles definem: circuncisão do prepúcio do pênis, mutilação do clitóris, cobertura completa do rosto, uso de quipás, de véus, de turbantes nas cabeças, uso de cachos nos cabelos, de barbas alongadas, de vestimentas compridas e sem adornos, ausência de calçados, etc. ${ }^{26}$ Nos conventos, como nas casernas, nas prisões, nos hospitais, nos hospícios, nos internatos, nas escolas fabricam-se corpos dóceis, produzem-se corpos que encarnam as disciplinas, as normas, as regras que definem esses próprios espaços institucionais. Os corpos são, assim, inseparáveis dos espaços e dos tempos que os formam e conformam, que os modelam e configuram. As carnes são moldadas e modeladas e tornam-se corpos a depender dos regramentos e normas que regem dados espaços, em dados tempos ${ }^{27}$.

Se o sexo é implantado nas carnes, se é a cultura e a sociedade que utilizam as diferenças anatômicas das carnes para estabelecer que umas carnes são carnes de machos e outros são carnes de fêmeas, o mesmo se dá com o processo de generificação, de atribuição de

\footnotetext{
${ }^{21}$ FOUCAULT, Michel. O nascimento da clínica. 7. ed. Rio de Janeiro: Forense Universitária, 2011.

${ }^{22}$ FRANCIS, Gavin. Da cabeça aos pés: histórias do corpo humano. Rio de Janeiro: Zahar, 2017; ALDERSEYWILLIAMS, Hugh. Anatomias: uma história cultural do corpo humano. São Paulo: Record, 2016.

${ }^{23}$ TOZER, A. W. A vida crucificada: como viver uma experiência cristã mais profunda. São Paulo: Vida Livros, 2013.

${ }^{24}$ PAULO II, João. Teologia do corpo: o amor humano no plano divino. Rio de Janeiro: Alêtheia, 2014; PIMENTEL, João Paulo. Glorificai a Deus no vosso corpo: conceitos e perspectivas da teologia do corpo. Curitiba: Aster, 2018.

${ }^{25}$ MOURA, Carlos Eugênio M. de. Candomblé: religião do corpo e da alma. Rio de Janeiro: Pallas, 2006.

${ }^{26}$ TRACTENBERG, Moisés. Psicanálise da circuncisão: judaísmo, cristianismo e islamismo e as mutilações genitais em crianças e adolescentes. Ribeirão Preto: FUNPEC, 2007.

${ }^{27}$ CANGUILHEM, Georges. O normal e o patológico. 7. ed. Rio de Janeiro: Forense Universitária, 2011.
} 
Outros Tempos, vol. 17, n. 29, 2020, p. 260 - 281. ISSN: 1808-8031

gênero. Nenhuma carne nasce masculina ou feminina, são assim classificadas numa dada ordem social e numa dada cultura ${ }^{28}$. Essa atribuição é arbitrária, embora seja arbitrada por códigos e instâncias sociais. O gênero é, antes de tudo, uma atribuição e uma função linguística, são as línguas que atribuem gênero às coisas e esses gêneros não têm, necessariamente, nada a ver com a materialidade da coisa que recebe a atribuição de gênero. Na língua portuguesa, coisas como a água, a bagagem, a arte são consideradas femininas, já na língua espanhola, uma língua tão próxima, são consideradas coisas masculinas. Há na língua inglesa um grande número de coisas que são neutras do ponto de vista de gênero, que não são nem masculinas, nem femininas. Isso demonstra o caráter cultural, situacional, histórico e consensual das identidades de gênero. Não é a natureza, nem a divindade que definem que algo é masculino ou feminino, é uma dada sociedade, uma dada cultura, através da língua que fala, dos conceitos de gênero que utiliza, que realizam as classificações das coisas segundo os gêneros. Como tem sobejamente demonstrado os etnógrafos, se o parentesco é a estrutura nuclear da maior parte das sociedades humanas, foi, em grande medida, a partir da gramática do parentesco, de suas categorias, que se classificou e se distribuiu todo o universo das demais coisas do mundo. À medida que esses grupos humanos fizeram da diferença anatômica entre as carnes humanas princípios de divisão e de classificação, à medida que sexuaram e generificaram as carnes humanas tenderam a sexualizar e generificar as demais entidades presentes em seu arredor, desde as manifestações da natureza até as manifestações do sobrenatural ${ }^{29}$.

Portanto, da mesma forma que ser macho ou fêmea é um atributo definido pela cultura, a partir da observância das diferenças anatômicas dos órgãos genitais, o mesmo vai se dar com a atribuição de um dado gênero, com a definição de carnes que seriam masculinas e outras que seriam femininas. Mas, da mesma forma que os casos de intersexualidade arruínam a divisão binária entre macho e fêmea, a divisão entre masculino e feminino vê-se ameaçada por distintas formas de identificação dos corpos que escapam a esse binarismo de gênero. Antes de ser invenções de uma pretensa "ideologia de gênero", essas carnes que se fazem corpos colocando em questão, borrando as fronteiras, tornando indecisas e ambíguas a divisão entre o masculino e o feminino, colocam desafios para uma cultura e uma ordem social que tende a alocar todas as carnes nessa divisão ${ }^{30}$. Se o masculino e o feminino já não podem ser declinados no singular, já que existem distintas maneiras de ser masculino e de ser feminino,

\footnotetext{
${ }^{28}$ STEARNS, Peter N. História das relações de gênero. 2. ed. São Paulo: Contexto, 2007.

${ }^{29}$ STRATHERN, Marilyn. O efeito etnográfico e outros ensaios. São Paulo: Ubu, 2017.

${ }^{30}$ CONNELL, Raewyn; PEARSE, Rebecca. Gênero: uma perspectiva global. São Paulo: Versos, 2015.
} 
Outros Tempos, vol. 17, n. 29, 2020, p. 260 - 281. ISSN: 1808-8031

numa mesma cultura, numa mesma ordem social, numa mesma época, se, ao longo do tempo, podemos observar distintas maneiras de encarnar as identidades de gênero, existem formas de elaboração dos corpos, de percepção do que seria o corpo próprio, o si mesmo, que colocam em xeque essa divisão entre carnes naturalmente masculinas e carnes naturalmente femininas. As identidades de gênero estão ligadas diretamente ao processo de autopercepção, ao processo de identificação, de como, a partir das carnes que nos são dadas ao nascer, construímos uma dada corporeidade e a alojamos ou não nessa divisão binária do gênero, como vemos e definimos o que seria o nosso próprio corpo. A chamada transexualidade, como o próprio prefixo trans deixa entrever, atravessa essa divisão binária, mantém uma posição de transversalidade em relação a ela ${ }^{31}$. Apesar de ter nascido com carnes que portam um órgão genital que o deveria alojar no gênero masculino, no processo de construção do corpo, um dado ser humano identifica-se e percebe-se como sendo feminino. Embora traga entre suas carnes um pênis, esse traço anatômico não consegue se transformar em marca social e cultural, não consegue ser transposto para o plano da cultura e não tem a força de fazer com que aquelas carnes, na hora de ser vista e pensada como corpo, adira à grade de classificação binária de gênero. A natureza ou a divindade, mais uma vez, quedam incapazes de definir por si sós a identidade que terá um dado corpo, que ele assumirá. Fabricar um corpo é, justamente, atribuir identidade particular às carnes com que se nasceu e um dos elementos que singulariza e particulariza corpos são as identidades de gênero. $O$ transexual nega que as carnes possam ser um destino, questiona o biológico como definidor de que corpos vamos ter. Suas carnes podem, inclusive, se tornar um peso, um anátema, uma conscrição da qual deseja fugir. É mais comum do que se pensa encontrarmos mulheres, corpos femininos, que trazem em suas carnes um pênis, e homens, corpos masculinos, que trazem em suas carnes uma vagina, o que torna explícita a cisão entre carnes e corpos e o binarismo das identidades de gênero que se apoia apenas nos detalhes anatômicos. Estamos diante, portanto, de outra maneira de viver o masculino e o feminino, de fabricar corpos a partir dessas referências sociais e culturais ${ }^{32}$.

\section{Outras masculinidades}

\footnotetext{
${ }^{31}$ JORGE, Marco Antônio Coutinho; TRAVASSOS, Natália Pereira. Transexualidade: o corpo entre o sujeito e a ciência. Rio de Janeiro: Zahar, 2018.

32 PATRIAU, Oswaldo Enrique Faverón. Nuevas categorías de sexos: autosexual, transgenero, bisexual, homosexual, heterosexual e asexual. São Paulo: Amazon E-Books, s/d.
} 
Outros Tempos, vol. 17, n. 29, 2020, p. 260 - 281. ISSN: 1808-8031

É na literatura que, com certa frequência, encontramos figuradas outras possibilidades de se construir corpos, de se fazer das carnes corporeidades dissidentes em relação aos modelos hegemônicos de sexo e gênero. Podemos dizer que, tal como pensou Michel Foucault, utopias de corpos, fantasias e sonhos de corporeidades outras ganham espaço na escrita literária ${ }^{33}$. A literatura tem sido capaz de enunciar e tornar visível corporeidades dissidentes, alternativas, transgressivas, minoritárias, singulares; de falar de corpos que fazem das carnes outros usos. Quero explorar, nesse texto, um conto da lavra do escritor pernambucano Marcelino Freire. Um conto breve, mas rico na apresentação de situações inusitadas quanto às alocações tradicionais das carnes e dos corpos no interior das classificações binárias de sexo e de gênero. O conto aborda uma das instituições mais decisivas na atribuição e no reforço dessas divisões binárias, macho e fêmea, masculino e feminino, quando se trata de fazer das carnes corpos: a família. Além disso, esse conto interessa-nos, particularmente, por apresentar personagens que encarnam distintas formas de ser masculino e feminino, formas que os tornam dissidentes em relação aos códigos hegemônicos de sexo e gênero. O conto intitula-se "Júnior" e encontra-se publicado no livro Rasif: mar que arrebenta, publicado no ano de $2008^{34}$.

Um pai convida um travesti (o autor usa o masculino, que é o que exige o uso "correto" da língua portuguesa, mas sabemos que o movimento social das travestis transformou um masculino num feminino, mudança de gênero que afeta assim os corpos e a linguagem) para tomar um café em sua casa. Primeira cena do conto e já temos dois personagens masculinos transgredindo, no uso de suas carnes e na elaboração de seus corpos, os atributos e as atribuições que definem socialmente o que seria esse lugar de gênero. Um pai que - lugar social tradicional para se alojar e se elaborar um corpo dito masculino -, tudo leva a crer, passou a noite com um travesti (e o uso do masculino aqui torna mais disruptiva a cena que se narra), passou a noite usando suas carnes de modo socialmente não admitido ou legitimado. Passou a noite elaborando o corpo de amante de um corpo feminino sui generis. E agora o convida para ir à sua casa tomar um café. Mais uma situação inusitada: não se costuma levar um travesti para tomar o café da manhã em casa. Um personagem, que não é familiar, convidado para compor uma cena de família. Por seu turno, o travesti (ou a travesti), na própria indefinição de qual gênero atribuir-lhe, expressa a ambiguidade de sua situação, situado entre as carnes que traz um pênis como órgão genital, que o tornaria um corpo masculino, e todos os demais recursos materiais e imateriais que utiliza para criar um corpo

\footnotetext{
${ }^{33}$ FOUCAULT, Michel. O corpo utópico, as heterotopias. São Paulo: N-1, 2013.

${ }^{34}$ FREIRE, Marcelino. Rasif: mar que arrebenta. São Paulo: Record, 2008.
} 
Outros Tempos, vol. 17, n. 29, 2020, p. 260 - 281. ISSN: 1808-8031

feminino. Ambiguidade que se amplia ao se ver convidado para prolongar sua performance feminina, de levar seu corpo feminino para além de uma noite de sexo e de hotel, para adentrar, uma manhã, numa cena familiar, em volta de uma mesa, saboreando um café ${ }^{35}$.

Estranhando o convite, por saber que o amante era casado, pergunta por sua mulher. Ficamos sabendo, portanto, que aquelas carnes ditas masculinas também ocupam outro lugar de sujeito legitimado e tradicional, também participam da fabricação de um outro corpo: o de esposo, o de marido de uma mulher. No estranhamento do travesti mais um deslocamento de posições consagradas de sujeitos, mediadas pelas identidades de sexo e gênero, enuncia-se como possibilidade: iria ele ocupar o lugar de mulher, de esposa daquele pai que o convida para um café em sua casa? Já ocupara, durante a noite, o lugar de amante, quem sabe de amada, agora iria também alojar suas carnes com pênis na fabricação de um corpo de esposa? Saberia ele/ela ser uma esposa, que partilha, ao amanhecer, o café da manhã com seu marido? Temos, portanto, um pai que apaga o cigarro, animado com a ideia de deixar aquele quarto de hotel, animado com a ideia de levar sua amante travesti para tomar um cafezinho rápido em sua casa. O travesti achou gozada a situação. Depois do gozo das carnes, durante a noite, o gozo subjetivo com seu deslocamento inesperado do lugar de amante para o lugar de esposa. Depois do gozo por se travestir, por deslocar suas carnes do lugar do masculino para o lugar do feminino, o gozo por deixar o lugar de mulher pública para se tornar uma mulher do lar, uma esposa que traz entre as carnes um pênis, situação mais do que gozada. Diz o narrador que, diante dessa situação, o travesti “sacudiu o ombro elástico, como um sol que se repõe" ${ }^{36}$. No dar de ombros, um deixar as coisas acontecerem, uma abertura para o devir, afinal sua vida era feita de abertura para possíveis. Ombro, carnes elásticas, capazes de adquirir novas formas, de delinear diferentes corpos, montados e desmontados. Como um sol que nasce, morre e renasce, que se põe e se repõe, o travesti, ser da noite, o/a amante noturno/a, estava nascendo esposa e mãe de família naquela manhã.

Chegaram a um sobrado onde a família vivia. O pai entrou pela cozinha sem fazer escândalo. Meio bêbado, com cheiro de cigarro molhado. Confessa, então, que gostava dessas aventuras, desses perigos a mais. Aventurar-se para além dos papéis tradicionais de sexo e de gênero, fazer suas carnes experimentarem prazeres, sensações e situações que os lugares legitimados de macho e de masculino não permitiriam, aventurar-se na experimentação perigosa de outras relações de sexo e de gênero, na perigosa fabricação de corpos alternativos e marginais o atraia e gerava prazer. Corpos que rescendem a cheiros viciosos como os do

\footnotetext{
${ }^{35}$ Ibid., p. 51

36 Ibid.
} 
Outros Tempos, vol. 17, n. 29, 2020, p. 260 - 281. ISSN: 1808-8031

álcool e do tabaco. O personagem mais fora do comum, aquele que seria um homem travestido de mulher, um corpo masculino que simula um corpo feminino, acha o outro, o pai, o esposo, o amante, aquele que parece obedecer em suas carnes e em seu corpo os códigos hegemônicos da masculinidade, um louco, um ser pinel, um ser demais. Cenas e personagens onde a racionalidade hegemônica, que preside a partição das categorias de sexo e de gênero, vê-se questionada e subvertida. O mundo parece ter enlouquecido naquela manhã, apesar de estarmos diante de uma cena banal e familiar, digna de anúncio de marca de margarina. Um homem entrando furtivamente pela porta da cozinha de sua casa, depois de uma noite de farra, cena normal e corriqueira, cena típica da vivência considerada normal e esperada da masculinidade, da qual a aventura e a escapada noturna são um traço esperado e até desejável. Um homem casado, com esposa, trazendo a amante da noite para entrar com ele pela cozinha e tomar um cafezinho, já não se constitui numa cena banal e costumeira. $\mathrm{O}$ respeito à moral familiar e à mãe de seus filhos não recomenda que tal cena aconteça. Imagine se a amante que entra furtiva pela cozinha é um/uma travesti, é uma amante cujo sexo é visto socialmente como sendo de um macho, cujo corpo é feminino e cujas carnes trazem, escondido em algum recôndito, um pênis ${ }^{37}$.

O pai convida o travesti a sentar. Coloca água para esquentar, ao mesmo tempo que o sol borbulha lá fora. O travesti, o ser que só sai às ruas com o pôr do sol, cujo calor das carnes enfrenta e ajuda a esquentar noites geladas, é um ser meio fora de lugar numa manhã de sol. Aliás, o fora de lugar é aí duplo: um travesti na cozinha de uma casa de família, em plena luz do dia. O travesti, um corpo fabricado para circular no espaço público, vê-se aí domesticado, levado para casa. Seu corpo está agora instalado num espaço que é visto socialmente como o espaço por excelência do feminino: a cozinha. E, no entanto, não é ela/ele que prepara o café, é o amante, o esposo, o marido, o pai de família. Ele que fez as carnes esquentarem de desejo, durante a noite fria, agora esquenta a água para o café, enquanto o dia também borbulha de calor ${ }^{38}$. É ele e não ela/ele que traz o biscoito, que põe a manteiga no prato. O homem da casa é também a mulher da casa, naquele momento. Aqueles dois corpos transitam não apenas entre a rua e a casa, mas transitam entre atributos e atribuições socialmente definidas para homens e mulheres, para o masculino e o feminino. Eles transitam na cozinha e entre lugares de sujeito. $\mathrm{O}$ dono da casa e a dona de casa que habitam as mesmas carnes, naquela situação, dirigem, então, uma pergunta ao/a travesti que soa, mais vez, irônica e derrisória: se ele/ela queria um pouco de ovo. Ele, que já lhe dera, durante a noite, 
Outros Tempos, vol. 17, n. 29, 2020, p. 260 - 281. ISSN: 1808-8031

possivelmente, muito do que se costuma, popularmente, chamar de ovos, agora volta a lhe oferecer o mesmo para seu dejejum. Mas, o mais irônico, é que todos naquela cena tinham um pouco ou muito de ovo. Os testículos, popularmente nomeados de ovos, é o símbolo por excelência do ser macho, são partes das carnes que servem de referência para nomeá-las de masculinas. Só que o personagem feminino da cena também porta ovos em suas carnes e aceita a oferta de ovos feita pelo seu parceiro, como parte de seu café da manhã, falando baixo como se tivesse certo pudor em aceitá-los. Ovos que comem e são comidos ali se misturam $^{39}$.

O pai, marido, amante diz que não é preciso que sua parceira fale baixo, pois sua mulher dorme "que nem uma pia quebrada" 40 . A verdadeira esposa, aquela que ocupa o lugar de dona da casa, de mãe de família, aquela que deveria estar à beira da pia, preparando o café da manhã, ainda dorme, como se fosse a própria pia quebrada. Ao perguntar pelo banheiro, e receber a pergunta de volta, em alto e bom som, o travesti desconfia que está sendo enganado, que aquele porra (ou aquele que emitiu tal coisa a noite passada ou aquele que a/o levou a emitir tal substância na noite anterior, afinal daquelas duas carnes se podia esperar derramamento de sémen) não tinha mulher nenhuma. Somente a pia de lavar louças, que se encontrava inteirinha à sua frente, na cozinha, dormitava naquele domicílio. Ele/ela desconfia que seu anfitrião vive sozinho, pois não se incomoda que se fale alto, no interior da casa, enquanto prepara a refeição matutina. Mais uma vez soa derrisória a afirmação de que ali não havia mulher nenhuma, afinal quem fazia a afirmação era alguém que submetia suas carnes a um longo e sofisticado processo de elaboração de uma figura de mulher. Ali perto da pia, bem inteiro, estava um corpo feminino, o corpo de uma mulher, embora feito com carnes que podiam, na hora do gozo sexual, expelir porra, como vulgarmente se nomeia o sémen emitido por carnes masculinas ${ }^{41}$.

O dono da casa indica, então, a localização do banheiro: na sala, a primeira porta à direita. O travesti dirige-se então ao banheiro, "pisando alto", "equilibrando-se no salto"42. Não há travesti sem sapato de saltos altos. Adereço fundamental na montagem de um corpo feminino, ele é, ao mesmo tempo, signo e expressão da feminilidade daquele corpo. Saber se equilibrar, saber andar pisando alto sobre saltos, uma arte indispensável, uma técnica corporal fundamental para a montagem de um corpo feminino ${ }^{43}$. A acoplagem entre pés e sapatos de

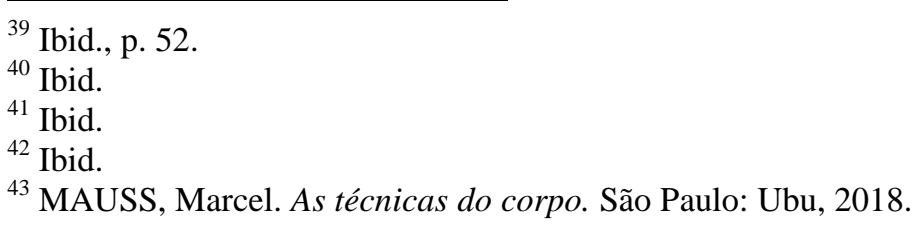


Outros Tempos, vol. 17, n. 29, 2020, p. 260 - 281. ISSN: 1808-8031

salto alto é, ao mesmo tempo, uma conexão técnica e a expressão de um sentido, de uma mensagem: aquele é um corpo de mulher, pois suspenso e movido pelo caminhar elegante e bem articulado sobre saltos. A montagem de um travesti ou uma travesti bem pode começar pelo gesto de calçar um sapato feminino. Os pés, que podem fazer parte de carnes vistas e ditas como masculinas, entram num devir mulher ao serem colocados, espremidos dentro de um sapato de salto alto. Quanto mais alto for os saltos dos sapatos, quanto mais difícil for a arte de se equilibrar sobre eles, quanto mais declaradamente tiverem formas e cores ditas femininas, mais indispensáveis e mais significativos serão na hora da montagem do corpo feminino. Gingando até o banheiro, diante da situação insólita em que se vê metido/a (depois de ter metido ou de ter sido metida, na noite anterior. Com um/a travesti nunca se sabe!) vai pensando com os seus saltos, apreensivo, como se a qualquer momento a polícia pudesse chegar e lhe perguntar: oh, viado, o que você está fazendo nessa casa ${ }^{44}$ Pergunta embaraçosa para uma mulher, que se vê agora nomeada como sendo um viado. Aquele corpo de mulher sendo destruído pela simples enunciação de uma frase policial e policialesca. Aquela mulher, amante, companheira de café da manhã do homem da casa, vê suas carnes serem desalojadas do lugar do feminino, para serem atiradas num lugar de sujeito indefinido, animalizado, um lugar desqualificado e subalterno socialmente: o lugar de viado. Aquele corpo continuaria não sendo reconhecido como um corpo masculino, o policial não encararia aquelas carnes como sendo de um macho, mas também não as reconheceria como sendo parte de um corpo feminino, como carnes pertencentes a uma fêmea, mas olharia para aquela figura ambígua e de difícil classificação dentro das categorias binárias de sexo e gênero e a alocaria numa espécie de limbo, de lugar nenhum, que seria o lugar de viado. Aquelas carnes nem seriam de um veado mesmo, o animal, nem de um homem ou de uma mulher, mas de um viado, forma popular e preconceituosa de se nomear o que seria o ser homossexual, tudo que aquele corpo rejeitava ao ser produzido. O travesti ou a travesti não quer ser viado, quer ser mulher, embora também, muitas vezes, se diga viado. Aquelas carnes, portanto, gingam, não apenas sobre os saltos, mas saltam, balançam, deslocam-se, coleantes entre as diversas gavetas classificatórias que desejam fazer ver e dizer qual seria o sexo e o gênero daquelas carnes e daquele corpo ${ }^{45}$.

Naquela manhã de romance familiar, ela ou ele temia a polícia. Temia o policiamento das carnes e dos corpos, que se fazem em nome da manutenção da ordem socialmente hegemônica de sexo e de gênero. Ele ou ela sabe que, seu corpo naquele espaço e

\footnotetext{
${ }^{44}$ FREIRE, op. cit., p. 52.

${ }^{45}$ Ibid.
} 
Outros Tempos, vol. 17, n. 29, 2020, p. 260 - 281. ISSN: 1808-8031

naquela cena, deslocando-se entre a cozinha e o banheiro de uma casa de família, é um caso de polícia. Que seu caso com o pai de família, que prepara seu café, é motivo de se ver levada ou levado à delegacia, por invasão de domicílio. Sendo pega ou pego na sala de uma casa de família, abrindo a porta, que fica à direita, podia ter, para ele ou ela, consequências sinistras: ser recambiada ou recambiado para a delegacia de polícia. Ao ser interrogado ou interrogada, diria algo pouco crível para as autoridades policiais, aquelas que militam para a manutenção da ordem, que defendem a manutenção das normas de sexo e de gênero, em nome da moral e dos bons costumes, que não veem com bons olhos qualquer ato de transgressão: "o cara me convidou para um café, ora, ora" ${ }^{" 46}$. Talvez os policiais interpretassem que estava querendo tirar um sarro da cara deles, que estava querendo rir deles, colocá-los numa situação risível. Possivelmente, terminaria aquela manhã romântica, aquela manhã de café tomado na cozinha do sobrado de família, atrás das grades de um xilindró. O romântico amante, aquele que, como uma prendada dona de casa, esquentara a água para o café, oferecera-lhe biscoitos com manteiga, compareceria à delegacia para declarar que levou seu ou sua amante, da noite anterior, para sua casa? Aquele exemplar do gênero masculino compareceria perante as autoridades para dizer que desfrutara os prazeres da carne com aquelas outras carnes vistas como de outro macho ou com aquele corpo feminino que, no entanto, portava em suas carnes pênis e escroto? Seria ele um cara escroto, a ponto de assumir que convidara um travesti para o café da manhã, em sua residência? ${ }^{47}$

Absorto nesses pensamentos, mijou e nem deu descarga. Gesto por demais masculino. Desleixo de macho num corpo de fêmea. O conto não entra em detalhes, mas podemos nos quedar imaginando, como será que aquelas carnes mijaram. Não portando uma vagina, pejorativamente apodada de carne mijada, como será que aquela mulher urinou, naquela manhã? Que dificuldades teve que enfrentar para tirar o órgão genital do seu esconderijo e poder, com ele, efetuar aquela mijada? Estando possivelmente aquendado, guardado para trás, escondido em meio às nádegas o pênis teve que ser libertado para dar aquela mijada. Talvez, em meio ao trabalho de reaquendar a neca, de recolocar aquele detalhe carnal em seu devido lugar, para que suas carnes voltassem a dar forma a um corpo feminino, tenha se esquecido de dar a descarga. Terá urinado de pé, como costumam fazer os homens ou terá, continuando com sua performance feminina até no recôndito escondido de um banheiro, urinado sentada? Sabemos apenas que, antes de deixar o banheiro, se olhou no primeiro espelho que encontrou. Gesto tido como eminentemente feminino, o olhar-se no espelho tem

\footnotetext{
46 Ibid.

${ }^{47}$ Ibid.
} 
Outros Tempos, vol. 17, n. 29, 2020, p. 260 - 281. ISSN: 1808-8031

aí uma enorme importância: ele permite a checagem se sua figuração do feminino continuava convincente, se sua performance do feminino continuava crível. Depois de uma noite de trabalho, depois de horas que aquele corpo feminino fora fabricado ele continuaria persuasivo? Espaço heterotópico, como nos apresentou Michel Foucault, o espelho dá espaço a utopias de corpos, como aquele que ela ou ele encarnava todas as noites ${ }^{48}$. Naquela manhã, depois de uma noite de amor, naquela casa, depois de uma mijada, continuava credível, continuava visível o seu corpo de sonhos, o seu corpo de desejo, o seu corpo de fantasia, o seu corpo feminino?

Diante do espelho diz para si mesma: "coragem, Magaly Sanchez, coragem!",49 Ficamos assim sabendo de seu nome de mulher. Tão fabricado e tão especial como seu corpo feminino. Não bastava se chamar Magaly, tinha que ser Magaly grafado com um Y, ironicamente a letra utilizada na genética para indicar o gene que definiria que as carnes a vir ao mundo apresentariam formas e características socialmente vistas e ditas como de um macho da espécie humana. Não uma Magaly qualquer, mas uma Magaly Sanchez. Quem sabe, uma senhorita espanhola. É preciso ter coragem para ser Magaly Sanchez, para fabricar um corpo feminino com carnes que são comumente atribuídas ao masculino. É preciso ter coragem de enfrentar o preconceito, a abjeção e a exclusão social de que são vítimas as travestis. Maior coragem, ainda, era requerida de Magaly Sanchez naquela manhã em que se tornara uma mulher de família, uma mulher do lar, uma mulher convidada para o café pelo seu amante noturno, por um pai e marido de uma outra mulher, que dormia, no quarto ao lado, como uma pia quebrada. Seu nome de artifício, seu nome de guerra, lembrava que dela era sempre exigida coragem, pois sua vida passava-se na batalha. Como um soldado, era na batalha que ganhava a vida e, tal como eles, a alcunha encobria um verdadeiro nome que, possivelmente, detestaria e gostaria de esquecer, um nome dito masculino, um nome de homem. O exagero na feminilidade de seu nome buscava reafirmar o pertencimento de sua identidade e de sua personalidade ao universo feminino. No artifício da nomeação a criação de um sujeito, de um Eu, de uma personalidade que se alocava na feminilidade.

O esposo, vendo-a hesitante, diz: "chega aí”, convidando-a para a degustação do repasto matinal. Ela e/ou ele, desconfiados, solicitam que o anfitrião lhe mostre uma foto da família. Indaga se a mulher da casa estaria viajando, incrédula ou incrédulo com a possibilidade de que a mulher não tivesse ouvido nada, nenhum barulho, nenhuma

\footnotetext{
${ }^{48}$ FOUCAULT. $O$ corpo... op. cit.

${ }^{49}$ FREIRE, op. cit., p. 52.
} 
Outros Tempos, vol. 17, n. 29, 2020, p. 260 - 281. ISSN: 1808-8031

movimentação desde a chegada deles. Ao que o amante responde com um "relaxa querida" Justo ela que demonstrou enorme habilidade em relaxamento na noite anterior. Ela que conseguira que seu parceiro relaxasse e gozasse, via-se agora aconselhada a relaxar, tensa diante da situação inusitada que estava vivendo. Podemos supor que o medo que o assalta ou a assalta, durante todo tempo, é o de que fosse expulsa ou expulso pela verdadeira dona da casa, pela verdadeira esposa, pela verdadeira mulher que ali habitava. Seu temor era o de ter sua condição de mulher, de amante e de convidada para um café da manhã escandalosamente contestada pela pia quebrada que dormia no quarto do casal. Sabia que, se a outra acordasse, com o barulho que faziam desde que chegaram, poderia se ver em meio a um barraco, a uma cena de violência e humilhação, que não ficaria sem resposta. Poderia ver seu romântico café da manhã transformado em pugilato, com direito a tapas, beliscões e puxões de cabelos e perucas. Poderia ver, literalmente, seu corpo feminino ser desmontado, reduzido à tristeza de suas carnes, vistas como de um macho. Poderia, na liça, perder partes vitais de seu corpo de mulher, não apenas a peruca e o sapato de salto alto, mas os brincos, os colares e pulseiras, sua meia-calça, seus sutiãs e sua bolsa, onde guardava o apurado, vindo do exercício da profissão.

Tranquilo, o marido pressuroso, entrega-lhe uma xícara colorida, com um café, que até que estava cheiroso. Trazendo, nas mãos, a sua própria xícara colorida, passa-lhe os biscoitos. São seis horas da manhã, responde-lhe o anfitrião ao ser perguntado. Seis da manhã $\tilde{n}^{51}$. Talvez sua vida nunca tivesse amanhecido tão colorida e cheirando tão bem, como naquela manhã. Tinha que degustar aquele momento e aquelas guloseimas, como se não houvesse amanhã. Sim, com leite, ele ou ela aceitava leite como acompanhamento do café (sempre aceitava leitinho, não era agora que iria recusar). Nesse passo do conto, o narrador lembra-se de não haver contado que o pai, no caminho de casa, passara em uma padaria e comprara seis pães quentinhos, possivelmente três para cada um dos convivas. $O$ travesti ficara no carro, sem acreditar no que estava lhe acontecendo ${ }^{52}$. Nunca, antes, um freguês, um cliente, a/o tinha convidado para ir até em casa tomar o café da manhã. Nenhum lhe havia levado até a padaria e lhe comprado pães quentes. Ele ou ela era que, ao acabar o expediente, no clarear da manhã, que fosse até um bar, uma lanchonete ou uma padaria, matar a sua fome, nascida do esforço necessário para o exercício de suas habilidades profissionais. Cansado, com os pés ardendo, apertados pelo sapato de salto, tinha que continuar a bater calçada, para

\footnotetext{
${ }^{50}$ Ibid.

51 Ibid.

${ }^{52}$ Ibid., p. 53.
} 
Outros Tempos, vol. 17, n. 29, 2020, p. 260 - 281. ISSN: 1808-8031

se alimentar e para ir para casa dormir. O que estava vivendo era o que pensava que devia se passar com todo casal apaixonado. Após uma noite de amor, amanhecer o dia comprando pão na padaria e tomando um café com leite, pão com manteiga e biscoitos. A cena da qual era agora personagem passava-se em seus sonhos de casamento e de parceria romântica. Se encarnava em seu corpo um sonho de mulher, era também uma mulher que sonhava em ter um namorado, um marido, um parceiro romântico que lhe levasse à padaria, no carro, e comprasse-lhe pão fresquinho ${ }^{53}$.

Ele, quase sempre, pejorativamente chamado de fresco, era uma mulher sonhadora e sensível, que, por instantes, viu brilhar uma alegria, em seu peito ${ }^{54}$. Frase e pensamento clichês que também soaram risíveis vindo de um travesti, afinal a que peito a frase se referia? A alegria brilhou em seu peito ou em seus peitos, questão, ao mesmo tempo, de número e de gênero. Usamos a palavra peito tanto para nomear a região do tórax de carnes ditas masculinas e também de carnes ditas femininas, quanto para nomear o que seriam os seios de carnes ditas fêmeas e de mulheres. Na construção de um corpo feminino, os seios têm uma importância fundamental. São os seios, as mamas, muito mais desenvolvidas nas carnes ditas femininas do que nas carnes ditas masculinas, que são marcadores diacríticos fundamentais para generificar e sexualizar essas carnes e transformá-las em corpos masculinos ou femininos. Talvez a construção de um corpo feminino inicie-se sempre pela adoção ou desenvolvimento de seios, de mamas bastante desenvolvidas. Se fazer travesti, quase sempre, começa pelo uso de mamas postiças, pelo uso de hormônio dito feminino para propiciar o crescimento "natural" das mamas ou pela aplicação de silicone para delineamento de seios. As chamadas bombadeiras são, quase sempre, travestis mais velhas e experientes que fazem a aplicação de silicone, que siliconizam as candidatas a travestis. Esculpir belas e volumosas tetas, dotar-se de poderosos peitos, pelos quais passarão fugazes alegrias ou não, é uma etapa decisiva na invenção de um corpo feminino ${ }^{55}$. Feitos de carnes ou de substâncias químicas, às vezes impróprias para o uso em seres humanos, os seios fazem com que carnes que, antes, podiam ser vistas e ditas como masculinas transformem-se, transitem para carnes vistas como femininas. A frase clichê, típica de romance B, torna-se derrisória numa situação em que o peito é um peito de travesti.

\footnotetext{
53 Ibid.

${ }^{54}$ Ibid.

${ }^{55}$ SILVA, Hélio R. S. Travesti: a invenção do feminino. Rio de Janeiro: Relume-Dumará, 1993.
} 
Outros Tempos, vol. 17, n. 29, 2020, p. 260 - 281. ISSN: 1808-8031

Mas, nesse peito, ou nesses peitos, também bate um coração. O travesti vê-se pensando: “O cara deve estar gostando de mim". Até o chamou de querida! ${ }^{56}$. Mas o pai, o amante, o possível apaixonado, não deu mais nenhuma palavra. Um silêncio pesado fez-se. "O travesti olhando a xícara e as migalhas. Correndo as unhas nas migalhas. Olhando o desenho dos pratos." Os pinguins da geladeira desconfiados. Os panos de enxugar pratos dobrados. "O travesti sem saber o que dizer" ${ }^{, 5}$. Será que seu anfitrião teria intuído seus pensamentos? Será que o silêncio constrangedor que fazia, no momento, na cozinha, denunciava o arrependimento daquele homem de tê-lo/tê-la trazido para casa? Será que ele também estava pensando que ele/ela estava gostando dele? Aquela alegria fugaz, que tinha passado, por um instante, pelo seu peito ou pelos seus peitos ia se tornando tristeza e embaraço. Aqueles dois corpos que haviam dialogado tão bem na noite anterior agora quedavam silenciosos, mudos, um diante do outro? Nem mesmo rir direito o travesti podia. Não podia soltar, ali, a sua gargalhada, uma marca de sua postura irônica diante da vida, diante das convenções sociais, da ordem social que transgredia. Se gargalhasse, o que ele ia achar? Que estava rindo dele, da situação e de seus corpos equívocos? Se soltasse uma gargalhada, a mulher dormindo igual uma pia quebrada podia acordar e, nisso, podia perder até seus dentes. Um travesti banguela é a apoteose da decadência. Na fabricação de seu corpo feminino, desejável e sedutor, não podia faltar uma bonita dentadura, até para esconder o pedaço de lâmina, que poderia lhe ajudar a se safar de situações de perigo e da polícia. Nem gemer, como fizera na noite anterior, podia. "Um travesti em silêncio é a coisa mais triste que alguém já viu, puta que pariu" ${ }^{58}$. É nesses momentos que a vida parece não ter fim, que o tempo se arrasta, que os minutos gotejam como um líquido viscoso. Levando ao exagero, em muitos momentos, o estereótipo socialmente delineado para o ser mulher, um/uma travesti deve ser faladeira, fofoqueira, ruidosa, não permanecendo calada um só momento. E agora, que pensara estar próximo de receber uma declaração de amor, e o que tivera foi um silêncio ensurdecedor?

Finalmente, enfrentando a situação embaraçosa, querendo pôr um fim a ela, pergunta ao dono da casa se pode ir. Foi quando uma criança, de dois ou três anos, a coisa mais lindinha em suas fraldas, apareceu e correu para o colo do travesti, gritando mamãezinha! O travesti jamais esqueceria aqueles olhos, os olhos daquele que de forma

\footnotetext{
${ }^{56}$ FREIRE, op. cit., p. 52.

${ }^{57}$ Ibid., p. 53.

58 Ibid.
} 
Outros Tempos, vol. 17, n. 29, 2020, p. 260 - 281. ISSN: 1808-8031

súbita e inesperada tornou-se o seu filho ${ }^{59}$. A ironia maior daquela cena era pensar que se suas carnes não seriam capazes de gerar e parir uma criança como aquela, pois suas carnes não traziam, em sua anatomia, órgãos que são referentes para que a sociedade defina como sendo femininas dadas carnes e dados corpos: faltava-lhe a vagina, o ovário, o útero, as trompas, mas, no entanto, seu corpo feminino, seu corpo elaborado e fabricado com carnes e próteses, com carnes e adereços, vestimentas, calçados, perucas, silicone, gestos e técnicas corporais fora capaz de lhe colocar no lugar de mãe, lugar tão valorizado socialmente e tido quase como sendo um destino para as mulheres. Ser mãe seria a afirmação máxima da feminilidade. A maternidade completaria um ser feminino, que ficaria a meias se não passasse por essa experiência definidora. Ora, ele, que trazia nas carnes um pênis, um escroto, testículos, traços anatômicos utilizados pela sociedade para dizer que essas carnes eram de um macho, que seu corpo era masculino, não foi impedido, nessa estranha manhã de vida familiar e doméstica, de tornar-se mãe. A criança a reconheceu como tal, e o reconhecimento, afinal, é um elemento socialmente central na atribuição de identidades.

Será que, de mulher dormindo naquela casa só existia mesmo a pia, afinal na língua portuguesa dão a esse objeto a condição de gênero feminino? Se o dono da casa, se o pai, se o homem daquele sobrado a trouxera para casa e se, agora, uma criancinha se atirava no seu colo chamando-o de mamãezinha, não estariam ambos carentes de presença feminina? Não faltaria àquela casa uma dona, uma mulher, uma mãe? O Júnior, o filho do pai, assim como ele fizera na noite anterior, encarapitou-se em seu colo, a procura de amor e carinho. $\mathrm{O}$ colo é uma parte que define o próprio corpo feminino, ele simboliza a feminilidade e a maternidade, ele simboliza a ação de cuidar, que socialmente é definida como uma atribuição feminina. Pôr alguém no colo é dar-lhe proteção e aconchego. Disponibilizar o colo é o gesto maior de acolhida, de abertura para o outro. Aquelas carnes portadoras de um pênis, transformadas em um corpo feminino, conseguiram, entre a noite e aquela manhã, ser travesti, ser puta, ser amante, ser namorada, ser esposa, e até ser mãe.

Esse conto de Marcelino Freire, extraordinariamente rico de nuances e sugestões, coloca-nos diante da precariedade, da ambiguidade, da labilidade das identidades de sexo e de gênero. Expõe, de forma lapidar, o caráter situacional das classificações baseadas nas distinções anatômicas e carnais. Deixa entrever a distinção necessária entre carnes e corpos, como os corpos são fabricações sociais que se utilizam das carnes, que as tomam como uma matéria essencial para suas elaborações, mas que a elas não se resumem, podendo, inclusive,

\footnotetext{
${ }^{59}$ Ibid.
} 
Outros Tempos, vol. 17, n. 29, 2020, p. 260 - 281. ISSN: 1808-8031

ignorá-las ou modificá-las. Esse conto deixa-nos ver distintas formas de ser masculino e feminino, muito distantes e distintas das figuras binárias que a ordem dominante de sexo e gênero pretende implantar nos corpos. Nele vemos que há mais masculinos do que podemos supor, há muitas formas de viver o masculino, muitas formas de ser homem, e muitas formas de deixar de sê-lo, de transitar para o feminino, ou permanecer no trânsito, na transversalidade, no trans, da transa e do transar. Carnes que portam um pênis, ao nascer, não estão condenadas, pela natureza ou por Deus, a serem carnes de macho e tornar-se corpo masculino. São possíveis, para essas carnes, outros caminhos de sexo e de gênero, porque não são as carnes que decidem os lugares que ocuparão, é a ordem social, é a cultura, é a linguagem, são, portanto, em última instância, os homens e mulheres constituídos por essas carnes que podem e devem ter o direito de dar a elas o sexo e o gênero que quiserem. 